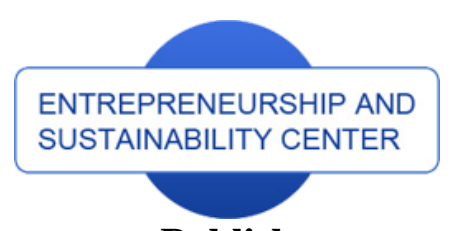

Publisher

http://jssidoi.org/esc/home

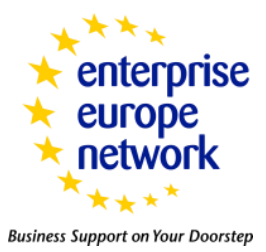

CASPA

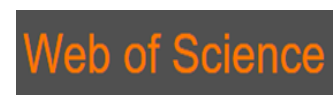

Clarivate
Analytics

\title{
TOWARDS THE SILK ROAD ECONOMIC ZONE INITIATIVE: HISTORICAL PERSPECTIVE
}

\author{
Ayula Zhylankozova \\ University of Foreign Languages and Business Career, Kazybek bi Street 168, Almaty, Kazakhstan \\ E-mail: zhylankozova78@mail.ru
}

Received 10 March 2018; accepted 10 October 2018; published 30 December 2018

\begin{abstract}
In contemporary conditions, the Great Silk Road remains the subject of modern historical research naturally intertwined with research in the area of sustainable development. Its significance caused not only by providing sales, but also cultural, scientific and diplomatic relations. Way, which arose, as a trade infrastructure, soon became an important factor of technical, scientific and spiritual progress of the population of different countries. The Silk Road segment on the territory of modern Kazakhstan as a historical gate of the Great Silk Road also has its specific international significance. Today the idea is re-emerging of renewing the way in a new historical incarnation and revival of the Great Silk Road in order to preserve and enhance its tremendous influence on the political, economic and cultural systems of the countries through which it passes.
\end{abstract}

Keywords: Great Silk Road; sustainable development; historical heritage; communication; trade exchange

Reference to this paper should be made as follows: Zhylankozova, A. 2018. Towards the Silk Road economic zone initiative: historical perspective, Entrepreneurship and Sustainability Issues 6(2): 548-557. http://doi.org/10.9770/jesi.2018.6.2(6)

JEL Classifications: B10, O1

Additional disciplines: history

\section{Introduction}

Well-developed communication infrastructure and means always has been precondition of economic cooperation of leading towards sustainable economic development of networking partners (Mingaleva et al. 2017; Monni et al. 2017; Prause, Atari 2017; Otter et al. 2017; Lavrinenko et al. 2016; Lavrinenko et al. 2017; Mikhaylov 2018). The legendary highway of the Middle Ages - The Great Silk Road is the subject of modern historical research, its 1,500-year history of the route is a world cultural and economic miracle. One of the branches of the famous trade route passed through the regions of Kazakhstan. The most important trading communications system, which is linked to the XV century East Asia to the Mediterranean, known as the Silk Road, the length was 7 th. $\mathrm{km}$. At the 


\section{The International Journal}

ENTREPRENEURSHIP AND SUSTAINABILITY ISSUES

ISSN 2345-0282 (online) http://jssidoi.org/jesi/

2018 Volume 6 Number 2 (December)

http://doi.org/10.9770/jesi.2019.6.2(6)

beginning of II millennium BC the Chinese took control of the way from China to the west. The formation and development of the Great Silk Road begins from this moment. Despite the fact that the trade routes have changed, two main routes have been identified on the map of the Great Silk Road: the southern and northern routes. South covered the territory from China to the shores of the Black Sea, ran through the lands of the Pamirs and the Aral Sea. The main trade hubs of this route were Syria, Iran, Central Asia, the south of Kazakhstan through the Talas and Chui valleys to Issyk-Kul, and it came out to the lands of Turkestan (Baypakov, 1998, 2009).

\section{Review of literature}

The northern part began in the basin of the Yellow River, crossed Central Asia, and led merchants to Iran and Syria, to the provinces of India. One of the branches of the Great Silk Road (northern) passed through the Kazakh lands, to the south and east, covering central territories and rushing westward (Gumilev 1999). The trade route had directions on the territory of Kazakhstan - the road from west to east as the main thoroughfare, which, starting from the second millennium BC. E., allowed to transfer goods from Shash to Sairam and further to the Ferghana Valley. Southeast direction was traders, striving to get to the Ili valley, the road ran through the south of Kazakhstan, its eastern regions and went to the lake Balkhash (Baipakov 1998, 1989, 2009; Baipakov et al. 2001). Thus, in the II millennium BC the intensive growth of large shopping centers on the territory of Kazakhstan was due to the formation and development of the Great Silk Road. A lot of trade routes, convenient access to large waterways made this region particularly lively.

\section{Materials and methods}

The significance of the Great Silk Road was not only in providing trade and economic ties, thanks to its cultural, scientific and diplomatic ties were established. The path that originally arose as a commercial, very soon became the most important factor in the technical, scientific and spiritual progress of mankind (Rtveladze 1999). In the process of communication, there was a cultural rapprochement and the establishment of connections between representatives of different tribes. Sold and bought products of silver and gold, jewelry made of precious stones, clothing made of fur. They were not only skillfully made, but also processed in a proper way, they were decorated with an authentic pattern or embroidery, original compositions were created that demonstrated the taste and aesthetic values of a particular people. Surprisingly beautiful silver jugs made by Byzantine craftsmen, porcelain products made in China, were discovered during the exploration of Talgar and Ispidzhab hillforts (Mamadazimov 2014). Remains of temples and religious buildings of all kinds were found in these shopping centers. This indicates that sages, pilgrims, travelers, creatively gifted people, who produced not only objects of worship, but also articles of secular character, flocked to the centers of trade. Thanks to this, there was a cultural exchange. Travelers who went along the silk route left records, diaries, composed songs and poems, wrote music. This greatest highway has contributed to the formation and development of diplomacy. The peoples of the East and the West were forced to contact, establish trade and political relations. Not the least, it has become possible due to the Silk Road segment that passes through the territory of present-day Kazakhstan. It should be noted that the area has historically become the gateway to the Great Silk Road (Gostin 2018). The settlements, located along the caravan route, developed intensively. The formation and rapid development of handicrafts by the Turkic peoples took place. Various technologies were developed for the production of goods, trade turnover increased, trade relations developed. Nomads and semi-nomadic Turkic tribes are gradually moving to a settled way of life. Trade routes that passed through the territory of Kazakhstan contributed to the establishment and development of such trade hubs as Otrar, Sairam, Taraz, etc. Urban culture is being formed, many-sided ties are being established with the world, socio-economic, political and cultural bases for the development of peoples inhabiting the territory are being formed Kazakhstan. Until the XIV century, the Great Silk Road retained its importance in the development of socio-cultural, political and economic ties. But with the development of sea trade routes, it has lost its position (Kembayev 2018; Gostin 2018). 
Today, world leaders are returning to the idea of renewing this highway in a new historical incarnation. Through the efforts of many states of the world it was decided to revive the Great Silk Road to a new life. An increasing number of people show a keen interest in the history of this ancient trans-national trade route, to unique monuments of ancient architecture, untouched spiritual values, bequeathed by famed ancestors, to national crafts, cuisine, traditions and festivals of the peoples of the region. The Silk Road had a tremendous impact on the formation of the political, economic, cultural structure of the countries through which it was held.. Along all its routes, large and small trading cities and settlements arose, especially carved by the caravan routes was Central Asia (Chaisse 2018). Dozens of trade routes crossed this region. Here, the most important ethnic processes took place, active interaction of cultures, large-scale trading operations were carried out, diplomatic treaties and military alliances were concluded. The peoples of this region have an outstanding role in the distribution of letter letters and world religions, many cultural and technical achievements to the countries of Inner Asia and the Far East.

As is known, the name "Silk Road" is associated with the precious in those days for Western goods - silk, who introduced the two worlds -West and East of the first in the history of mankind transcontinental road. But it would be unfair to reduce the importance of the Great Silk Road in the history of world civilization exclusively to the trade in silk. Its role was much wider and more diverse, because it was caravans not only with various eastern and western goods, but also penetrated spiritual values, religious ideas. Despite the last statement, it was during the heyday of the Silk Road in the $1-\mathrm{V} 111$ centuries, and then the $1 \mathrm{X}-\mathrm{X} 111$ centuries. The people of the East, as never before, began to realize the importance of cultural ties, close communication, began to develop common cultural values, and common traditions appeared in the culture of the peoples of the Eurasian space. Despite the last statement, it was in the heyday of the Silk Road that the peoples of the East, as never before, began to realize the importance of cultural ties, close communication, began to develop common cultural values, and common traditions appeared in the culture of the peoples of the Eurasian space. Silk Road carried mainly silk, which along with gold has become an international currency, they are gifts to kings and ambassadors paid a salary of mercenary troops and government debt. In turn, from Rome, Byzantium, India, Iran, the Arab Caliphate, and later from Europe and Russia, goods were produced from these countries (Azovsky 1999). On the Silk Road, the famous horses of Ferghana, Arabian and Nisian horses, camels and elephants were brought for sale and much more. Religious ideas also spread along the Silk Road. Various missionaries carried their faith in the overseas countries. Buddhism came from India through Central Asia and Eastern Turkestan, Christianity spread from Syria, Iran, and Arabia, and then Islam spread. The greatness of the Silk Road is not so much in that colossal commodity exchange between different states, as in the interpenetration and mutual enrichment of dissimilar civilizations and cultures. The Silk Road is a system of ancient trade caravan roads leading from China to the countries of the Middle East and Europe, one of the most significant achievements in the history of world civilization. The Silk Road had a tremendous impact on the formation of the political, economic, cultural structure of the countries through which it was held (Baipakov 1989, Tang et al. 2017).

\section{Results}

At the beginning of the third millennium, mankind faced the need to seek new ways of cooperation or restore forgotten, sand-stained centuries. Comprehensive, integrated research and restoration of the Great Silk Road, as "path of dialogue", it corresponds to a need. For many centuries the Great Silk Road served as a rapprochement between different peoples, the exchange of ideas and knowledge, the mutual enrichment of languages and cultures. Of course, in those distant times there were political conflicts, wars broke out, but the Silk Road was invariably revived. The ineradicable desire for enrichment, for reasonable profit and higher prosperity, has always prevailed over political and religious confrontation. Therefore it is necessary to use such a powerful example when creating a model for future relations and cooperation between the peoples. 


\section{The International Journal}

ENTREPRENEURSHIP AND SUSTAINABILITY ISSUES

ISSN 2345-0282 (online) http://jssidoi.org/jesi/

2018 Volume 6 Number 2 (December)

http://doi.org/10.9770/jesi.2019.6.2(6)

Globalization, which has become one of the leading trends of world development at the turn of the 20th and 21st centuries, has an increasingly deeper impact on the socio-economic, military-political and other spheres of human life, including the character of international life (Mikheev 2015; Královičová, Žatko 2016). Integration of the former Soviet republics among themselves and with the world economy, the search for their own place on the international scene, defending national interests for inclusion in regional and global policy takes place in the context of globalization, which has both positive and negative sides. The drive for globalization processes, rapidly integrating capital, technology, services and information, is world trade. By linking all new countries, regions and entire continents into unified networks, history influences the nature, intensity, duration of bilateral and multilateral relations, forcing the interaction of states that were not partners before. The Silk Road revitalization project corresponds to global development trends, creating new opportunities for the development of trade relations between Asia and Europe, uniting the efforts of many countries at different levels of economic development and differing in their political order.

In May 1993 in Brussels, the European Commission organized a meeting of representatives of the states of Central Asia and the Caucasus, as well as the European Union. The purpose of the meeting was to consider the possibility of integrating into the world economy new independent states - the countries of Central Asia and the Caucasus. In 1998, the UNESCO international organization announced the launch of a ten-year project entitled "Integral study of the Silk Road - the way of dialogue". The project provides for a broad and comprehensive study of the history of civilizations, the establishment of close cultural contacts between the East and the West, the improvement of relations between the numerous peoples inhabiting the Eurasian continent. The project of the revival of the ancient transnational highway - Great Silk Road, put forward by the world community in the early 90 's. In the 20th century, it became a reflection of the desire of many states and authoritative organizations to expand the zones of stability and the space of trust, to stimulate economic and political cooperation among the young independent states among themselves and with the developed states of Europe and the Asia-Pacific region, and an attempt to realize the perspective idea of Euro-Asian transit (Jinping 2015a,b; Surie 2018). Historically, on the Great Silk Road along the Northern transport dry land route from Asia to Europe, the leading place is occupied by Kazakhstan and Russia, which are in an extremely favorable geopolitical position, being on a large transport and trade transit of goods from Asia to Europe. The intensification of cooperation within the framework of the SCO and the Eurasian Economic Union attaches particular importance to the revival of the land intercontinental transport project. So, within the framework of the Eurasian Economic Union, the concept of the transport union has already been adopted, which creates the institutional preconditions for cooperation on one of the most difficult sections of the new Silk Road, with sufficient reserves in the transport infrastructure in this region. One of the tasks of the SCO is also the intensification of trade and economic cooperation between the member countries. TRACECA - the international transport corridor Europe-Caucasus-Asia, allocated in the quality of an independent Euro-Asian transport corridor, it does not include the communications of the PRC and other East Asian states. The idea of the project (TRACECA, Transport Corridor Europe-Caucasus-Asia) was first announced at a conference in Brussels in May 1993 with the participation of 8 republics of the former USSR Azerbaijan, Georgia, Armenia, Kazakhstan, Turkmenistan, Uzbekistan, Kyrgyzstan, and Tajikistan. The project was supported by the European Union, which finances through its Tacis program its main activities, as well as the United States of America, which officially recognized it as an alternative to Russian transport communications (in April 1999 in Washington in the framework of the 50th anniversary of NATO special meeting on the TRACECA project).

The corridor of "TRACECA" is interpreted as a modern modification of one of the directions of the Great Silk Road, the idea of its revival acquired special popularity in the Central Asian states after the collapse of the USSR. Official TRACECA route: ports of the Western Black Sea coast (Istanbul, Constanta, Varna, Odessa); ferrying across the Black Sea - Poti (Georgia), Tbilisi (Yerevan), Baku; crossing over the Caspian Sea - Turkmenbashi - 
The International Journal

ENTREPRENEURSHIP AND SUSTAINABILITY ISSUES

ISSN 2345-0282 (online) http://jssidoi.org/jesi/

2018 Volume 6 Number 2 (December)

http://doi.org/10.9770/jesi.2019.6.2(6)

Bayram, Samarkand, Tashkent, Shymkent, Bishkek, Almaty, Dostyk. The TRACECA connection with the European transport system is via Istanbul port, Constanta port, Varna port, Odessa port, Danube river. With the Asian transport networks, the TRACECA corridor is connected through the Kazakh-Chinese border station Dostyk. The main objectives of TRACECA are: the development of trade, transport and communication links between Europe, the Black Sea region, the Caucasus, the Caspian Sea region and Asia; facilitating access to world markets for Member States by road and rail; ensuring road safety, cargo security and environmental protection; Harmonization of transport policy and related legal structures; creation of a competitive environment for carriers from member states.

The European Union, as well as leading economic powers and trading states such as the United States, Japan, China and Russia, showed interest in TRACECA and created projects or organized interactions with it. There are different points of view regarding the prospects for the implementation of the TRACECA transport corridor between Europe and East Asia through China, Kazakhstan, Central Asia, the Caspian, the Caucasus and the Black Sea. Transport cooperation here is one of the main directions [Chaisse, Julien 2018]. The planned increase in ties between the member states will make the Great Silk Road of the 21 st Century even more demanded, not only as a purely transit route to the countries of Europe, but also as a more convenient option for delivering goods to the SCO countries. Therefore, a revival of the Great Silk Road is a politically and economically necessary condition for the development of international trade, and for Kazakhstan and Russia this is an added plus, since the transit of goods is considered on the Northern transport route from Asia to Europe (Mihnev 2016, Remyga 2015). The project provides an opportunity for States to implement with maximum efficiency advantages of its geographical position, to build a modern infrastructure here to upgrade given the world economy needs an existing industrial potential, create new jobs and improve living standards.

Kazakhstan and China since ancient times are friendly neighbors, which are reliably united by the Great Silk Road. Since the establishment of diplomatic relations, cooperation between the two countries has been successfully developing in all spheres, especially in the cultural sphere. Days of culture of two countries, weeks of cinema, tours of creative teams and individual performers, scientific and technical and art exhibitions, porcelain and silk exhibitions are regularly held in Kazakhstan and China, which creates a fertile ground for interpenetration and mutual enrichment of cultures. A significant project in the field of conservation and protection of monuments of cultural and historical heritage was the cross-border serial nomination of the Silk Road monuments for inclusion in the UNESCO World Heritage List. Representatives of 10 states, international experts from UNESCO and ICOMOS took part in the sub-regional seminar held in Xi'an. It was a global task - to determine the specific routes of the Great Silk Road for inclusion in the first serial nomination. Historical sources say that Xi'an, which was the ancient capital of many Chinese dynasties, was the starting point of the Great Silk Road, the unique objects of the world cultural and historical heritage, including the most famous - the Terracotta army, have been preserved here. Only after visiting China, you clearly see and begin to realize that the Chinese civilization, which originated about five thousand years ago, is one of the oldest in the world. Modern China is a dynamically developing and at the same time mysterious country with a lot of interesting historical and cultural attractions. History and culture of Kazakhstan for many centuries developed in close contact and interaction with eastern and western civilizations. Thanks to the state program "Cultural Heritage", it became possible to replenish and expand Kazakhstan's source-research and information-historical base with copies of archival materials from foreign collections that have a huge historical and cultural significance (Sazonov 2015). Thus, scientists of the Institute of Oriental Studies named after RB Suleimenov, working in the First Historical Archive of China, discovered unique materials on the history of Kazakhstan, as well as information on the history of the relationship of the Ch'ing Empire with neighboring states in 1741-1828. This is more than 500 archival documents in Chinese, over 60 in Chagatai, more than 40 in Oirat, and more than 3,000 in Manchu. All these priceless documents have become unique sources for studying the history of Kazakhstan. Important documents on diplomatic relations were also found in the archives: Kazakh-Chinese, Kazakh-Russian, Kazakh-Kyrgyz, Kazakh-Kokand, Kazakh-Oirat, 
The International Journal

ENTREPRENEURSHIP AND SUSTAINABILITY ISSUES

ISSN 2345-0282 (online) http://jssidoi.org/jesi/

2018 Volume 6 Number 2 (December)

http://doi.org/10.9770/jesi.2019.6.2(6)

evidencing a multi-vector cooperation policy. On the Silk Road, along which caravans with silk, tea and gunpowder went to the west, and in the opposite direction - with horses, carpets, jade, corals and other goods from Central Asia, culture flourished. The art of the "Great Highway" was multi-genre: music, dances, various performances, of course, painting. We can imagine how Buddhism from India gradually penetrated into the countries along the Silk Road, as evidenced by the ruins of Buddhist temples discovered by archaeologists in Central Asia, including in Kazakhstan. A painting by Giuseppe Castiglioni "Kazakhs are presented gifts with horses" (1757) was found thanks to the efforts of scientists of the Institute of Oriental Studies at the famous National Museum of Oriental Art in Guimet, Paris, where relics of the peoples of the East. To date, this is the only picture that depicts the diplomatic ceremony of giving gifts in the form of three horses. The canvas depicts the fact that the Kazakh emperor Qianlong was given gifts to the Chinese emperor as a sign of union and friendship. (Sherman 2000). Studies conducted by scientists of the Institute of Oriental Studies confirmed that the events presented in this picture belong to the era of the reign of Ablai Khan in Kazakhstan and Emperor Qianlong in China. This proves that there were diplomatic and trade relations between the Kazakh and Qing rulers. It was during this period that fairs were opened on the principle of "silk in exchange for horses". A rich history of economic and cultural relations between Kazakhstan and the Celestial Empire has found its continuation in modern times. In Astana at the International Specialized Exhibition EXPO-2017, the Chinese side approved Kazakhstan as the main country of tourist trips for PRC citizens in 2017. This serves as a good example of good neighborly relations and support by the Chinese government of Kazakhstani international projects (Kaczmarski 2017, Xu et al. 2017; Tang et al. 2017).

The Silk Road is actively reviving today and regaining its place on the world map, now as the great highway of the new century and the new millennium. Among the joint projects on the revival of the ancient route can be called the Transcontinental Transport Corridor "Western Europe - Western China", which is of great importance for the development of the Kazakh economy. In 2014, the capital of Qatar made a historic decision on the joint application of Kazakhstan, China and Kyrgyzstan. The Great Silk Road was inscribed on the UNESCO World Heritage List. The popular route of the Chang'an-Tien-Shan corridor begins with the famous cities of Xian / Chang'an / and Luoyang, which were the ancient capitals of China, and ends in Central Asia - in Kazakhstan's Zhetysu region. The total length of the famous corridor exceeds five thousand kilometers. For many centuries, this segment of the Silk Road has successfully linked peoples and states. In the long term, it is planned to include other routes of the great ancient road to the UNESCO list. We can confidently say that the revival of the Silk Road, the great friendship and success is sure to continue highway and achieve new successes, strengthened the friendship of Kazakhstani and Chinese people (Alonso 2017, Habal 2017).

\section{The discussion of the results}

The Silk Road Economic Zone Initiative, part of the historic "One Belt - One Way" initiative, in recent years has become an integral part of China's foreign policy. The concept of the new Silk Road, proposed in 2013, launched in 2015, involves investing in roads and railways and ports, which should recreate the old Silk Road, substantially enriching neighboring regions. The proposed trade corridors should connect the territories of Xinjiang, Pakistan, Afghanistan and some other states with Europe, although an exact plan for a completely reconstructed path has not yet been published. The project is officially called the "Silk Road economic belt and maritime Silk Road of the XXI century" (or for the sake of brevity "One belt and one way"). One of the main ideas of this initiative is to connect the five post-Soviet countries: Kazakhstan, Uzbekistan, Turkmenistan, Kyrgyzstan and Tajikistan. Any country participating in a large-scale initiative to transform the infrastructure of the region will receive unprecedented investment from China and, most likely, real advantages. It is believed that the history of the Silk Road was peaceful and that it did not know wars, conquests and imperialism. China also speaks of this initiative as "happy", "peaceful" and also quite consistent with the principle of win-win (double winnings) (Auezov 1999). It is distinguished by Beijing's unprecedented foreign policy activity. It is quite logical in this connection to raise 
The International Journal

ENTREPRENEURSHIP AND SUSTAINABILITY ISSUES

ISSN 2345-0282 (online) http://jssidoi.org/jesi/

2018 Volume 6 Number 2 (December)

http://doi.org/10.9770/jesi.2019.6.2(6)

two questions: first, how the Economic belt of the Silk Road meets the interests of the PRC, and secondly, how in practice the initiative is implemented in the space of the Eurasian Economic Union (Ostrovskii 2017). The main practical interests of the PRC are as follows. Firstly, this is a continuation and expansion of the one started in the late 1990s. The policy of "Greater Western Development" - the accelerated development of the lagging economically conflict-prone western regions of the PRC through the successful expansion of their trade, transport and logistics, financial ties with the neighboring states of Eurasia. Secondly, it is the continuation and expansion of the "Exit Outward" economic policy actively implemented by the previous Chinese leadership, which provided for the withdrawal of "excess" capital from the state (Tang et al. 2017; Xu et al. 2017). As the economic model of the PRC is revised (instead of the former export orientation - expansion of domestic consumption and services), there is a trend towards a gradual withdrawal of surplus manufactures, including environmentally unreliable ones, abroad. Thirdly, the initial strong emphasis on the economic belt of the Silk Road was made on joint infrastructure projects and on the construction of infrastructure facilities outside the PRC. This is explained, among other things, by the fact that the construction sector has developed in scale in the previous decades and provided a huge number of jobs. In a situation where a number of key projects (for example, in the sphere of highspeed road traffic, energy infrastructure) have been successfully implemented, and the pace of real estate construction in the crisis situation of this sector has decreased, internal challenges associated with unemployment are increasing. In addition, according to statistics, China's labor market annually increases by 20 million people. In such circumstances, the importance of going beyond the PRC for construction companies is growing. The projects proposed in the framework of the economic belt of the Silk Road for related loans meet these requirements. Thus, the practical interests of the PRC in The economic belt of the Silk Road are due, first of all, to the tasks of internal development and the removal of internal tension (Petrovsky (Ed.) 2016; Spechler 2018).

At the international and global levels, Beijing's need to respond to the processes of creating new geo-economic and geopolitical constructs, which can be considered, including deterrence of the PRC (for example, the projects of the Trans-Pacific Cooperation, the Transatlantic Partnership, the Eurasian Economic Union), is added to them. In Belarus, the economic belt of the Silk Road initiative was actively supported. The main in the process of joint promotion of the economic belt of the Silk Road was the implementation of the joint industrial park "Great Stone" project in the Belarusian territory. As it is known, the construction of the park was envisaged from May 2012. Initially, the shares of the parties were determined: $60 \%$ for the PRC and $40 \%$ for the Republic of Belarus, the prospects for the development of electronic technologies, biomedicine, robotics, cooperation in the field of logistics and etc. Then there was a slowdown around the project. As the Chinese side of the economic belt of the Silk Road moved forward, the parties came to a variant of a more specific interface between the economic belt of the Silk Road and the construction of a techno-park in the Republic of Belarus. Given the greater share of the Chinese side in this project, it can be assumed that the adjustment of practical conjugation goals is also influenced by the interests of the Chinese side. The official rhetoric of the PRC at the bilateral level is sustained in the neoliberal tradition. In contrast, the expert discourse in the PRC regarding the Chinese-Belarusian interaction can be correlated with the tradition of the neo-realistic: first of all, it takes into account the interest of Beijing in promoting The economic belt of the Silk Road, assesses the economic situation in Belarus, trends in BelarusianRussian relations and to a lesser degree in the relations of Belarus with the states of the European Union. The economic belt of the Silk Road is characterized by Chinese specialists as a new historical opportunity for Kazakhstan, Belarus and other countries.

\section{Conclusions}

The Great Silk Road influenced the development of world culture. The Kazakh steppe was a territory through which trade routes passed. During the trade, the economic and cultural relations of the nomadic and sedentary 
The International Journal

ENTREPRENEURSHIP AND SUSTAINABILITY ISSUES

ISSN 2345-0282 (online) http://jssidoi.org/jesi/ 2018 Volume 6 Number 2 (December) http://doi.org/10.9770/jesi.2019.6.2(6)

population interacted, and the spiritual cultures of the various tribes merged. The importance of the Great Silk Road was not only in providing trade and economic ties. Thanks to it, cultural, scientific and diplomatic ties were established. The path that originally arose as a commercial, very soon became an important factor in the technical, scientific and historical progress of mankind. Thus, the history of the Great Silk Road is the history of a broad cultural interaction and mutual exchange between the peoples of the East and the West (Haiyan 2018). It proves that only close cooperation and mutual enrichment of cultures are the foundation of peace and progress for all of humanity. The Silk Road had a tremendous impact on the formation of the political, economic, cultural structure of the countries through which it passed.

\section{References}

Antonio, A. 2017. Los Intereses De China En Asia Central, Belt And Road, Revista UNISCI 45: 67-84. https://doaj.org/article/a2535c863ab74f19840b92113e5da076

Auezov, M. 1999. China's -Kazakhre lations: history and modernity, Central Asia and the Caucasus 3 (4): 65-74.

Azovsky, I. 1999. Silk Road on the eve of the XXI century, Central Asia and the Caucasus 2 (3): 12-17.

Baipakov, K.M. 1989. Silk Road as a conductor of spiritual culture and art, Bulletin of the Academy of Sciences of the Kazakh SSR, 3:1618.

Baipakov, K.M. et al. 2001. Early medieval culture of the Seven Rivers and Southern Kazakhstan on the Great Silk Road/K. Baypakov, Z. Shaimerdenova, S. Peregudova. - Almaty: Fылым, 240 p.

Baypakov, K.M. 1998. Medieval cities of Kazakhstan on the Great Silk Road. Almaty: Fyliy, 216 p.

Baypakov, K.M. 2009. The Great Silk Road (on the territory of Kazakhstan). Almaty: Ed. Aruna

Chaisse, J.; Matsushita, M. 2018. China's 'Belt And Road' Initiative: Mapping the World Trade Normative and Strategic Implications, Journal Of World Trade 52(1):163-185. http://apps.web of knowledge.com

Chen, D.; Yang, Z. 2018. Systematic optimization of port clusters along the Maritime Silk Road in the context of industry transfer and production capacity constraints, Transportation Research Part E-Logistics And Transportation Review 109: 174-189, https://doi.org/10.1016/j.tre.2017.11.007

Gostin, L. O. 2018. China's "New"Silk Road, British Medical Journal, 360: k816 https://doi.org/10.1136/bmj.k816

Gumilev, L.N. 1999. Ancient Turks. M., chapter IV: Silk and caravan path. p. 252-264

Habal, M. B. 2017. The Silk Road to Modern Times: An Exchange of Education, Culture, and Knowledge for the Best Patient Quality of Life, Journal of Craniofacial Surgery 28(6): 1393-1394, https://doi.org/10.1097/SCS.0000000000004020

Gostin, L.O. 2018, China's "new" silk road, Bmj-British Medical Journal, Volume: $360 \quad$ Article Number: k816 https://doi.org/10.1136/bmj.k816

Haiyan, X.; Xi, C.; Yan, B. 2018. The Green Silk Road Economic Belt and the Governance of the Aral Sea, China an International Journal Volume 16(1): 90-106 http://apps.webofknowledge.com/full

Jinping, S. 2015 b. Joint construction of the 21st century sea Silk Road. Economic belt of the Silk Road. Moscow: Russian Biographical Institute; Institute of Economic Strategies. p. 15-20.

Jinping, S. 2015a. Joint construction of the economic belt of the Silk Road. Economic belt of the Silk Road. Moscow: Russian Biographical Institute; Institute of Economic Strategies. p. 8-14. 
Kaczmarski, M. 2017. Non-western visions of regionalism: China's New Silk Road and Russia's Eurasian Economic Union, International Affairs 93(6): 1357-1376 https://doi.org/10.1093/ia/iix182

Kembayev, Z. 2018. Implementing the Silk Road Economic Belt: from the Shanghai Cooperation Organisation to the Silk Road Union? Asia Europe Journal 16(1): 37-50 https://doi.org/10.1007/s10308-017-0483-4

Královičová, M.; M. Žatko, M. 2016. One belt one road initiative in Central Asia: implications for competitiveness of Russian economy Working Paper No. 2016/9 https://www.msm.nl/resources/uploads/2016/09/MSM-WP2016-9.pdf

Lavrinenko, O.; Ohotina, A.; Amosova, J.; Teivāns-Treinovskis, J. 2017. Intercompany networks of the cross-border region (LatviaLithuania-Belarus), Journal of Security and Sustainability Issues 7(1): 39-54. https://doi.org/10.9770/jssi.2017.7.1(4)

Lavrinenko, O.; Ohotina, A.; Tumalavičius, V.; Pidlisna, O. V. 2016. Assessment of partnership development in cross-border regions' innovation systems (Latvia-Lithuania-Belarus), Journal of Security and Sustainability Issues 6(1): 155-

166. https://doi.org/10.9770/jssi.2016.6.1(12)

Mamadazimov A. 2014. The Great Silk Road. The history of formation, flowering and decay. Dushanbe: Sino, 384

Mikhaylov, A. S. 2018. Socio-spatial dynamics, networks and modelling of regional milieu, Entrepreneurship and Sustainability Issues 5(4): 1020-1030. https://doi.org/10.9770/jesi.2018.5.4(22)

Mikheev, V.; Lukonin, S.; Zhe S. 2015. Multivariance: Xi Jinping's Big Strategic Response, World Economy and International Relations12: 11.

Mihnev M. 2016. China and Kazakhstan cooperation on the Silk Road, International Journal of Applied and Fundamental Research 1: $96-97$

Mingaleva, Z.; Sheresheva, M.; Oborin, M.; Gvarliani, T. 2017. Networking of small cities to gain sustainability, Entrepreneurship and Sustainability Issues 5(1): 140-156. https://doi.org/10.9770/jesi.2017.5.1(12)

Monni, S.; Palumbo, F.; Tvaronavičienè, M. 2017. Cluster performance: an attempt to evaluate the Lithuanian case, Entrepreneurship and Sustainability Issues 5(1): 43-57. https://doi.org/10.9770/jesi.2017.5.1(4)

New Silk Road and Its Importance for Russia/Ed. V.E. Petrovsky (Ed.), A.G.Larina (comp.) E.I. Safronova. - Moscow: DeLi Plus, 2016. $234 \mathrm{p}$.

Ostrovskii, A. V. 2017. Prospects to Interface the Silk Road Economic Belt and the Eurasian Economic Union Projects, Herald of the Russian Academy of Sciences 87(6): 480-490 https://doi.org/10.1134/S1019331617060041

Otter, C.; Watzl, C.; Schwarz, D.; Priess, P. 2017. Towards sustainable logistics: study of alternative delivery facets, Entrepreneurship and Sustainability Issues 4(4): 460-476. https://doi.org/10.9770/jesi.2017.4.4(5)

Prause, G.; Atari, S. 2017. On sustainable production networks for Industry 4.0, Entrepreneurship and Sustainability Issues 4(4): 421431. https://doi.org/10.9770/jesi.2017.4.4(2)

Remyga, V.N.; Padalko, V.I. 2015. China's new global strategy is the Economic belt of the Silk Road. Economic belt of the Silk Road. Moscow: Russian Biographical Institute; Institute of Economic Strategies. p. 61-71

Rtveladze E.V. 1999. The Great Silk Road: Encyclopedic Guide: Antiquity and the Early Middle Ages. Т.: Узбекистан миллий энциклопедияси [The National Encyclopedia of Uzbekistan], 280 p.

Sazonov, S.L.; Kudryavtsev, E.S., Wu, Z. 2015. Transport component of the projects of conjugation of the Eurasian Economic Union and the economic belt of the Silk Road. Problems Dal.

Sherman G. 2000. The New Central Asia: In Search of Stability. Washington (D.C.) 
The International Journal

ENTREPRENEURSHIP AND SUSTAINABILITY ISSUES

ISSN 2345-0282 (online) http://jssidoi.org/jesi/

2018 Volume 6 Number 2 (December)

http://doi.org/10.9770/jesi.2019.6.2(6)

Spechler, M. C. 2018. Uzbekistan: The Silk Road to Nowhere?, Contemporary Economic Policy Vol. 18 https://doi.org/10.1111/j.14657287.2000.tb00026.x

Surie, P. 2018. China's Asian Dream, Empire Building Along the New Silk Road, China Report 54(1): 143-146 https://doi.org/10.1177/0009445517744413

Tang, K.; Li, Z.; Li, W.; et al. 2017. China's Silk Road and global health, Lancet 390(10112): 2595-2601 https://doi.org/10.1016/S0140$\underline{6736(17) 32898-2}$

Xu, L.; Fan, X.; Wang, W. 2017. Renewable and sustainable energy of Xinjiang and development strategy of node areas in the "Silk Road Economic Belt", Renewable \& Sustainable Energy Reviews 79: 274-285. https://doi.org/10.1016/j.rser.2017.05.031

Register for an ORCID ID:

https://orcid.org/register

Copyright (C) 2018 by author(s) and VsI Entrepreneurship and Sustainability Center

This work is licensed under the Creative Commons Attribution International License (CC BY).

http://creativecommons.org/licenses/by/4.0/

(c) (†) Open Access 